(c) Musikhina I.V., Yazykova A.B., Vlasov M.V., Gordinskaya N.A., Lebedev M.Y., Aleynik D.Y., Tenilin N.A., 2021

DOI 10.18019/1028-4427-2021-27-1-32-37

\title{
Innate immunity, bone and cartilage metabolism in children with developmental dislocation of the hip - pilot study
}

\author{
I.V. Musikhina, A.B. Yazykova, M.V. Vlasov, N.A. Gordinskaya, M.Yu. Lebedev, D.Ya. Aleynik, \\ N.A. Tenilin
}

Privolzhsky Federal Medical Research Centre, Nizhny Novgorod, Russian Federation

\begin{abstract}
Objective Search for the relationship between innate immunity and bone and cartilage metabolism in patients with developmental dislocation of the hip (DDH). Material and methods The study included 27 patients with DDH who underwent reduction of the hip at pediatric orthopaedic department of the Federal State Budgetary Educational Institution of Higher Education «Privolzhsky Research Medical University» of the Ministry of Health of the Russian Federation. The patients aged $15.0 \pm 1.7$ months. The study enrolled the babies diagnosed with grades III, IV, V unilateral or bilateral DDH as classified by M.V. Volkov, 1978. Patients with hip dysplasia (grade I DDH) or congenital hip subluxation (grade II DDH) were excluded from the study. The control group consisted of 15 patients without musculoskeletal pathology. The mean patients' age was $24.0 \pm 1.8$ months. Peripheral blood monocytes, toll-like receptor (TLR2, TLR4, TLR5) expression, serum concentrations of fibroblast growth factors (FGF), vascular endothelial growth factor (VEGF), serum magnesium, type I, II collagen and aggrecan were measured in patients of major and control groups. Results DDH patients showed statistically significant differences in all the parameters measured except for the type 2 collagen with decrease in peripheral blood monocyte and increase in TLR2 and TLR5 expression, slight increase in the serum magnesium with decreased concentration of aggrecan and increased FGF level. There was a two-fold decrease in VEGF level and a two-fold increase in type I collagen concentration. There were moderate significant correlations for monocyte matches TLR2 and TLR2 - TLR5 in major group. Three main factors detected with factor analysis included (1) monocytes, TLR2 and TLR5 as most meaningful, (2) FGF and type 2 collagen and (3) aggrecan. Conclusion The findings suggested that specific factors of innate immunity can be involved in the pathogenesis of DDH. Toll receptors regulate many metabolic pathways and connective tissue metabolism, More studies are needed to further explore this topic.
\end{abstract}

Keywords: developmental dislocation of the hip, innate immunity, bone and cartilage metabolism

\section{INTRODUCTION}

In recent years, advances in biochemistry and molecular biology have enabled research of the basic aspects of the etiopathogenesis of some diseases including developmental dislocation of the hip (DDH), in particular, suggesting the condition being one of the manifestations of dysplastic syndrome. DDH is one of the most common and severe pathologies among pediatric diseases of the hip joint. DDH occurs in 3-4 cases per 1000 newborns in Russia [1]. For many decades, research has been conducted on the pathology, with most of the works reporting either methods of surgical treatment of the disease or the diagnosis. The understanding of the etiopathogenesis of the disease has not improved considerably in recent years. Although significant progress has been made to allow timely diagnosis and proper treatment of $\mathrm{DDH}$, neither functional nonsurgical nor early surgical treatment can secure full recovery, and the reasons behind this are not always clear.

DDH diagnosed at birth can predispose a child to premature degenerative changes and dysplastic hip arthritis. New surgical interventions fail to offer essential solutions for the treatment of such a complex pathology as DDH. We need a new look at the disease with a different approach in investigating causes of DDH to develop efficient antenatal prophylaxis. In recent years, DDH has been associated with undifferentiated connective tissue dysplasia [2]. Connective tissue dysplasia is a unique ontogenetic maldevelopment being one of the most complex problems of modern medicine. Clinical manifestations of undifferentiated connective tissue dysplasia are diverse and nonspecific involving different organs and systems and can often be difficult to diagnose. A significant number of publications report impaired connective tissue development in patients with visceral pathology (heart failure, gastrointestinal diseass, pulmonary and neurological disorders). There is little data overall describing the condition in patients with congenital malformations of the musculoskeletal system with a few publications reporting some pathological aspects of the complicated condition [3, 4].

Promisingdirectionsidentifiedinthestudyofcongenital orthopedic diseases associated with undifferentiated connective tissue dysplasia are to determine the factors leading to the condition, investigate processes of collagen synthesis and breakdown, define biomarkers for early diagnosis and evaluate the effectiveness of treatments 
[5-7]. Meanwhile, several studies report the role of the immune system in functioning of metabolic pathways and maintaining homeostasis, and the involvement in the pathogenesis of many diseases [8-10].

Objective of the study was to search for the relationship between innate immunity and bone and cartilage metabolism in patients with DDH.
The study was performed in accordance with ethical principles for medical research involving human subjects stated in the Declaration of Helsinki developed by the World Medical Association as revised in 2000 and Order of the Ministry of Health of the RF dtd 19th June 2003 No. 266 on Clinical guidelines in the Russian Federation.

\section{MATERIAL AND METHODS}

The study included 27 patients with DDH who underwent surgical treatment at pediatric orthopaedic department of the Federal State Budgetary Educational Institution ofHigher Education «Privolzhsky Research Medical University» of the Ministry of Health of the Russian Federation. The cases were grouped homogeneously. The patients aged $15.0 \pm 1.7$ months. The study enrolled the babies diagnosed with grades III, IV, V unilateral or bilateral DDH as classified by M.V. Volkov, V.D.Dedova (1972). Patients with hip dysplasia (grade I DDH) or congenital hip subluxation (grade II DDH) were excluded from the study. All the patients were admitted to the hospital for hip reduction using tailored techniques. The specimen were collected prior to treatment.

Bilateral involvement was detected in 13 patients whose severity of hip dislocation was graded as III $(n=4)$, IV $(n=6)$ and V $(n=3)$. More severe involvement of the left side was observed in eight patients and six patients had more severe involvement in the right hip including grade III $(\mathrm{n}=4)$, grade IV $(\mathrm{n}=8)$ and grade $\mathrm{V}(\mathrm{n}=2)$ dislocations. None of the patients had signs of dystrophy in the hip joint. Different interventions were employed for the patients depending on the severity and age. Hip reduction was performed for 27 patients using a functional apparatus of our design $(n=5)$, overhead traction $(n=4)$, closed reduction and spica casting $(\mathrm{n}=1)$, and Ludloff's open reduction $(n=11)$. Five patients with severe DDH underwent open hip reduction performed according to the classical method combined with intertrochanteric correcting osteotomy and Salter pelvic osteotomy.

The control group consisted of 15 patients without musculoskeletal pathology. The mean patients' age was $24.0 \pm 1.8$ months. Peripheral blood monocytes, toll-like receptor (TLR2, 4, 5) expression, serum concentrations of fibroblast growth factors (FGF), vascular endothelial growth factor (VEGF), serum magnesium, plasma type I, II collagen and serum aggrecan were measured in patients of major and control groups. Mononuclear cells (MNCs) were isolated from peripheral heparinized blood ( 25 units per $1 \mathrm{~mL}$ ) by gradient centrifugation at $1500 \mathrm{rpm}$ (ficoll-urographin $\rho=1.077$ $\mathrm{g} / \mathrm{cm} 3$ ) for 40 minutes and washed twice with RPMI 1640 medium at $1500 \mathrm{rpm}$ for 10 minutes to measure monocytes and innate immunity factors. Expression of TLR2 and TLR4 on peripheral blood MNC monocytes was determined immediately after their isolation with incubation of PC5-labeled antibodies to CD14 (Beckman Coulter, USA), PE-labeled antibodies to TLR2 (CD14+CD282+), APC-labeled antibodies to TLR4 (CD14+CD284+) and FITC -labeled antibodies to TL5(CD 14+CD 285+) (BD Bioscience, USA) with appropriate isotypical controls (Vescmap Coulter) for 30 minutes at $4^{\circ} \mathrm{C}$. The expression of CD14, TLR2, TLR4, and TLR5 was analyzed using Navios flow cytometer (Beckman Coulter, USA). The percentage of monocytes carrying TLR2, TLR4, and TLR5 on their surface was estimated.

A R\&D systems kit (USA) was used to measure fibroblast growth factor (FGFb), and eBioscience kit (USA) was used to measure vascular endothelial growth factor (VEGF-A). Type I and type II collagens was measured using a Cloud-Clone Corporation (USCN) Human COLLAGEN ELISA Kit. Aggrecan levels were measured using PG-ELISA BCM Diagnostics kits. Optical density was recorded with the Sunrise analyzer (Austria) using the Magellan program automatically building a calibration plot and measuring concentration of the study agents. Serum magnesium concentration was photometrically measured with commercially available Vector-Best kits.

Written informed consent was obtained from each subject or the subject's parent/legally acceptable representative. Statistical analysis was performed using the tools of StatSoft Statistica 6.0 software. Nonparametric statistical tests were used in both groups in the absence of normal distribution of variables. Correlation and factor analyses were used to describe variability among observed, correlated variables.

\section{RESULTS}

Statistically significant differences between the groups were detected for all the parameters measured in patients of the main and control groups using the
Wald-Wolfowitz test, except for type 2 collagen. The percentage of monocytes was reduced in the main group as compared to the control group with 
an increase in the proportion of TLR-2 and TLR-5 (Table 1).

Serum magnesium level was slightly increased in patients of the main group $(p=0.001)$, urine aggrecan was decreased in DDH patients $(\mathrm{p}=0.001)$ and the fibroblast growth factor (FGF) was increased $(\mathrm{p}=0.001)$ (Table 2$)$. The main group showed a twofold decrease in the level of VEGF $(p=0.001)$ as compared to the control group along with a twofold increase in type I collagen $(p=0.001)$ while type II collagen level showed no significant differences between the groups (0.059) (Table 2).

Significant average correlations were found for monocyte pairs, TLR $2(\mathrm{R}=-0.47, \mathrm{p}<0.05)$ (negative) and TLR2 - TLR-5 $(\mathrm{R}=0.55, \mathrm{p}<0.05)$ in the main group. The factor analysis showed the parameters being grouped into three classes in the experimental group with monocytes, TLR-2 and TLR-5 being included in the first class, FGF and type 2 collagen being in the second class and aggrecan being in the third class (Fig. 1). Factor one featured characteristic value of 2.72 with the total percentage of variance being 27.17 ; factor 2 showed characteristic value of 1.64 with the total percentage of variance being 16.44 ; factor 3 demonstrated characteristic value of 1.25 with the total percentage of the variance being 12.55. Accordingly, there was a significant decrease in significance from 1 to 2 (approximately twice) and then to factor 3 .

Table 1

Monocytes and TLR-2,4,5 measured in patients of the main and control groups using the Wald-Wolfowitz runs test

\begin{tabular}{|c|c|c|c|}
\hline \multicolumn{4}{|c|}{ Innate immunity } \\
\hline \multirow{2}{*}{ Parameters } & \multicolumn{2}{|c|}{ Median [Q25-Q75] } & \multirow{2}{*}{$\mathrm{p}$} \\
\hline & DDH patients, $\mathrm{n}=27$ & Healthy persons, $n=15$ & \\
\hline Monocytes & $1.93[1.150-2.65]$ & $2.60[2.60-5.40]$ & $0.001 *$ \\
\hline TLR-2 & $20.40[16.605-24.20]$ & $18.70[9.26-18.8]$ & $0.001 *$ \\
\hline TLR-4 & $1.54[0.89-2.22]$ & $1.11[0.98-1.67]$ & $0.001 *$ \\
\hline TLR-5 & $4.77[3.248-11.66]$ & $5.01[3.58-5.93]$ & $0.001 *$ \\
\hline
\end{tabular}

Note: *significant differences $(\mathrm{p}=0.001)$; TLR-2, 4,6 - Toll-like receptor-2,4,6

Table 2

Connective tissue metabolism measured in patients of the main and control groups using the Wald-Wolfowitz runs test

\begin{tabular}{|c|c|c|c|}
\hline \multicolumn{4}{|c|}{ Connective tissue metabolism } \\
\hline \multirow{2}{*}{ Parameters } & \multicolumn{2}{|c|}{ Median [Q25-Q75] } & $\mathrm{p}$ \\
\hline & DDH patients, $n=27$ & Healthy persons, $\mathrm{n}=15$ & \\
\hline Magnesium & $0.95[0.900-1.00]$ & $0.86[0.86-0.96]$ & $0.001^{*}$ \\
\hline Aggrecan, $\mathrm{mcg} / \mathrm{mL}$ & $7.99[6.955-6.62]$ & $7.24[6.81-13.18]$ & $0.001 *$ \\
\hline FGF, $\mathrm{pkg} / \mathrm{mL}$ & $6.01[2.548-12.58]$ & $1.39[1.38-1.40]$ & $0.001 *$ \\
\hline VEGF, pkg/mL & $487.73[250.00-632.84]$ & $729.98[630.18-1437.76]$ & $0.001 *$ \\
\hline Type I collagen, $\mathrm{pkg} / \mathrm{mL}$ & $2911.10[2196.100-5933.00]$ & $1932.50[1325.10-2846.40]$ & $0.001^{*}$ \\
\hline Type II collagen, $\mathrm{pkg} / \mathrm{mL}$ & $30000.0[7366.350-30000.0]$ & $30000[13595.00-30000.00]$ & 0.059418 \\
\hline
\end{tabular}

Note: *significant differences ( $\mathrm{p}=0.001)$; FGF, fibroblast growth factor; VEGF, vascular endothelial growth factor.

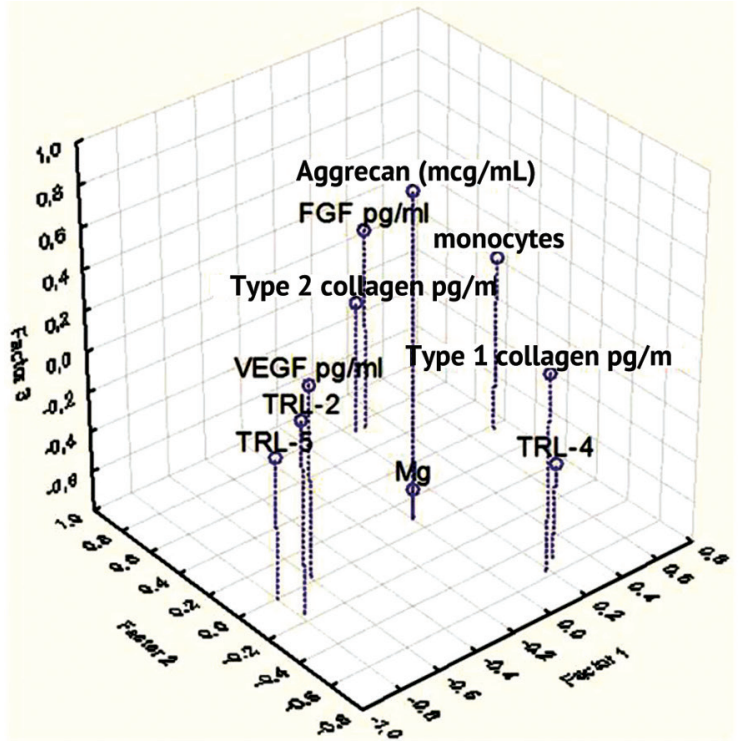

Factor Loadings,

Factor 1 vs. Factor 2 vs. Factor 3

Rotation: Varimax raw

Extraction: Principal components
Fig. 1 Results of the factor analysis in the main group 


\section{DISCUSSION}

Current scientific data are consistent with the theory describing Toll-receptors as indicators of innate immunity that play an active role in the pathogenesis of some types of dysplasia [12-14]. There is evidence of TLR involvement in the development of inflammatory response and malignancy through possible activation of the NF-kB pathway [15]. TLR2 is known to have broad specificity [16] and plays a role in the activation of the MAPK (mitogen-activated protein kinase) oncogenic pathway with increased expression of TLR2 promoting the dysplastic-to-hyperplastic transition. One of the preliminary conclusions is that the innate immunity in DDH is under stress and can cause or initiate changes in the connective tissue.

TLR are pathogen recognition receptors that trigger innate immune responses through induced secretion of cytokines activating multiple steps in the inflammatory reactions. Toll-2 and Toll-4 receptors bind to lipopolysaccharides and peptidoglycans in connective tissue regulating the signaling processes of inflammation and apoptosis. An increased level of blood Toll-receptors may indicate an inflammatory process and microbial burden to be properly investigated with regard to connective tissue metabolism.

Aggrecan is a large chondroitin sulfate proteoglycan, the most common non-collagenic protein in the cartilage, being essential for the function and maintenance of normal cartilage structure. It binds type 2 collagen and, like many proteoglycans, retains water improving tissue tone and resistance of articular cartilage to heavy loads. Increased release of aggrecan molecules during cartilage degradation in mutations of the ACAN gene expressing aggrecans is known to lead to a wide phenotypic spectrum of non-lethal skeletal dysplasia including spondyloepimetaphyseal dysplasia, spondyloepiphyseal dysplasia and various non-specified short-growth syndromes associated with accelerated bone maturation with the decreased level indicating the predominance of anabolic processes and a decreased level of cytokines [17, 18]. The level of aggrecan in the cartilage matrix was reported to be significantly reduced in patients with acquired hip dysplasia [19]. In vitro study performed by E.I.Schelkunova et al. [20] showed that a reduced ability to synthesize aggrecan can result from changes in cell metabolism during a pathological process in the articular cartilage of the knee. Further study is needed to identify the role of aggrecans in the signaling pathways of connective tissue metabolism [18].

Fibroblast growth factors (FGFs) make up a large family of polypeptide growth factors. In addition to the subgroup that includes FGF-11 and FGF-14, FGF, they exhibit the diverse biological activity through binding to a number of tyrosine kinase receptors (FGR receptors, FGFR) which are encoded by four genes. FGF proteins control a large number of physiological processes, since almost all cell lines originating from the embryonic mesoderm and neuroectoderm are under their control $[21,22]$. FGFs are responsible for regulating cell division, cell cycle, angiogenesis, activation of signaling cascades, as well as for migration, differentiation, tissue regeneration, and keratinocyte growth. Elevated levels of FGF stimulates angiogenesis in the cartilage being one of possible reasons for deficient cartilage; reduces the absorption of phosphorus being a perspective marker of calcium-phosphorus metabolism because its excess signaling reduces the absorption of phosphorus resulting in chronic hypophosphatemia, mineral and bone disorders. FGF23 is significantly increased in osteomalacia.

Vascular endothelial growth factor (VEGF) is a family of polypeptides that promotes arterial, venous and lymphatic vasculogenesis [23] and plays an important role in tumor growth and metastasis [24], although no association between VEGF mutations and neoplasia has been found [25]. A decreased VEGF level may be associated with the development of dysplasia, impaired development of bone and cartilage tissue and endothelium. There is evidence of a significant role of VEGF in the remodeling of cartilage tissue [26]. The decreased VEGF levels observed in our series may be a sign of dysplasia, impaired formation of bone and cartilage tissue and endothelium.

Collagen, as the main component of connective tissue, is found everywhere in the human body and many different diseases are associated with mutations in collagen genes.Type I collagen with a greater mechanical strength can be found everywhere in the skin, bones and cartilage providing a normal structure and strength to the joints. The increased level of type I collagen in some types of dysplasia may be associated with vascular invasion into the pathological cartilage that can also undergo fibrous replacement associated with dedifferentiation of chondrocytes and the transfer from synthesis of type II collagen to type I collagen [23]. We agree with the authors reporting genetic prerequisites for imperfect synthesis of the interstitial cartilage substance, congenital skeletal abnormalities, weakness of the tendon-ligamentous apparatus and other disorders $[27,28]$. Decreased aggrecan level and increased type I collagen level in the main group could be likely to 
result from originally deficient cartilage coverage of the femoral head and acetabulum in patients with DDH. A significant increase in the type I collagen level could also indicate to pathological changes in the articular cartilage due to vascular invasion or fibrous degeneration. This can be caused by changes in the immune system in children with DDH with impaired cartilage coverage of the articulating surfaces of the hip joint. The findings can be indicative of significant changes in innate immunity in patients with DDH.

\section{CONCLUSION}

The findings suggested that specific factors of innate immunity can be involved in the pathogenesis of DDH. Toll receptors regulate many metabolic pathways and connective tissue metabolism to be further explored. Further research of innate immunity in patients with
DDH can be practical for the development of objective diagnostic and prognostic criteria for determining the severity of undifferentiated connective tissue dysplasia in hip dislocation and evaluating the effectiveness of conservative and surgical treatment of the patients.

\section{REFERENCES}

1. Baindurashvili A.G., Voloshin S.Iu., Krasnov A.I. Vrozhdennyi vyvikh bedra u detei grudnogo vozrasta: klinika, diagnostika, konservativnoe lechenie [Congenital hip dislocation in infants: clinical picture, diagnosis, conservative treatment]. $2^{\text {nd }}$ Ed. SPb., SpetsLit., 2016, 103 p. (in Russian)

2. Tvorogova T.M., Vorobeva A.S. Nedifferentsirovannaia displaziia soedinitelnoi tkani s pozitsii dizelementoza u detei i podrostkov [Non-differentiated connective tissue dysplasia from the position of diselementosis in children and adolescents]. Russkii Meditsinskii Zhurnal, 2012, vol. 20, no. 24, pp. 1215-1221. (in Russian)

3. Beliaeva E.L., Zemtsovskii E.V. Osobennosti patologii verkhnikh otdelov zheludochno-kishechnogo trakta u lits molodogo vozrasta s sindromom displazii soedinitelnoi tkani serdtsa [Characteristics of the pathology of the upper gastrointestinal tract in young people with dysplasia of the heart connective tissue]. Gastroenterologiia Sankt-Peterburga, 2005, no. 1-2, pp. 28-32. (in Russian)

4. Moskovich G.I., Dulkin L.A., Geniatulin R.U. Kliniko-morfologicheskie osobennosti sindroma razdrazhennogo kishechnika u detei na fone nedifferentsirovannoi soedinitelnotkannoi displazii [Clinical-and-morphological characteristics of the irritable bowel syndrome in children on the background of non-differentiated connective tissue dysplasia]. Voprosy Prakticheskoi Pediatrii, 2008, vol. 3, no. 1, pp.19-25. (in Russian)

5. Solyeyko O.V., Osypenko I.P., Galych T.V., Chernykh M.O. Assessment of rehabilitation potential in patients with vascular dysfunction caused by undifferentiated connective tissue dysplasia. Wiad. Lek., 2017, vol. 70, no. 2, pt. 2, pp. 282-285.

6. Arita M., Fertala J., Hou C., Kostas J., Steplewski A., Fertala A. Prospects and limitations of improving skeletal growth in a mouse model of spondyloepiphyseal dysplasia caused by R992C (p.R1192C) substitution in collagen II. PLoS One, 2017, vol. 12, no. 2, pp. e0172068. DOI: 10.1371/ journal.pone.0172068

7. Khokhlova O.I., Kalaeva G.Iu., Ust'iantseva I.M. Characteristics of the bone tissue metabolism in adolescents with the connective tissue's undifferentiated dysplasia. Fiziol Cheloveka, 2014, vol. 40, no. 3, pp. 101-108. (in Russian)

8. Pearce E.L., Pearce E.J. Metabolic pathways in immune cell activation and quiescence. Immunity, 2013, vol. 38, no. 4, pp. 633-643. DOI: 10.1016/j. immuni.2013.04.005

9. Ganeshan K., Chawla A. Metabolic regulation of immune responses. Annu. Rev. Immunol., 2014, vol. 32, pp. 609-34. DOI: 10.1146/annurevimmunol-032713-120236

10. Villarino A.V., Kanno Y., O'Shea J.J. Mechanisms and consequences of Jak-STAT signaling in the immune system. Nat. Immunol., 2017, vol. 18, no. 4, pp. 374-384. DOI: 10.1038/ni.3691

11. Volkov M.V., Dedova V.D. Detskaia ortopediia [Pediatric Orthopaedics]. M., Meditsina, 1972, 240 p. (in Russian)

12. Zhang Z., Liu Q., Liu M., Wang H., Dong Y., Ji T., Liu X., Jiang Y., Cai L., Wu Y. Upregulation of HMGB1-TLR4 inflammatory pathway in focal cortical dysplasia type II. J. Neuroinflammation, 2018, vol. 15, no. 1, pp. 27. DOI: 10.1186/s12974-018-1078-8

13. Trotta T., Porro C., Calvello R., Panaro M.A. Biological role of Toll-like receptor-4 in the brain. J. Neuroimmunol., 2014, vol. 268 , no. 1-2, pp. 1-12. DOI: $10.1016 /$ j.jneuroim.2014.01.014

14. Koh J., Kurago Z.B. Expanded Expression of Toll-Like Receptor 2 in Proliferative Verrucous Leukoplakia. Head Neck Pathol., 2019, vol. 13, no. 4, pp. 635-642. DOI: 10.1007/s12105-019-01028-y

15. Kurago Z.B., Lam-ubol A., Stetsenko A., De La Mater C., Chen Y., Dawson D.V. Lipopolysaccharide-squamous cell carcinoma-monocyte interactions induce cancer-supporting factors leading to rapid STAT3 activation. Head Neck Pathol., 2008, vol. 2, no. 1, pp. 1-12. DOI: 10.1007/ s12105-007-0038-X

16. Kawai T., Akira S. The role of pattern-recognition receptors in innate immunity: update on Toll-like receptors. Nat Immunol., 2010, vol. 11, no. 5, pp. 373-384. DOI: 10.1038/ni.1863

17. Gibson B.G., Briggs M.D. The aggrecanopathies; an evolving phenotypic spectrum of human genetic skeletal diseases. Orphanet. J. Rare Dis., 2016, vol. 11, no. 1, pp. 86. DOI: 10.1186/s13023-016-0459-2

18. Tompson S.W., Merriman B., Funari V.A., Fresquet M., Lachman R.S., Rimoin D.L., Nelson S.F., Briggs M.D., Cohn D.H., Krakow D. A recessive skeletal dysplasia, SEMD aggrecan type, results from a missense mutation affecting the C-type lectin domain of aggrecan. Am. J. Hum. Genet., 2009, vol. 84, no. 1, pp. 72-79. DOI: 10.1016/j.ajhg.2008.12.001

19. Feng W.J., Wang H., Shen C., Zhu J.F., Chen X.D. Severe cartilage degeneration in patients with developmental dysplasia of the hip. IUBMB Life, 2017, vol. 69, no. 3, pp. 179-187. DOI: 10.1002/iub.1606

20. Shchelkunova E.I., Voropaeva A.A., Russova T.V., Baitov V.S. Sintez agrekana i kollagena II tipa in vitro khondrotsitami iz raznykh zon kolennogo sustava bolnykh gonartrozom [Synthesis of aggrecan and type II collagen in vitro by chondrocytes from different zones of the knee of patients with gonarthrosis]. Sovremennye Problemy Nauki i Obrazovaniia, 2016, no. 6, pp. 1-10. (in Russian)

21. Olsen S.K., Garbi M., Zampieri N., Eliseenkova A.V., Ornitz D.M., Goldfarb M., Mohammadi M. Fibroblast growth factor (FGF) homologous factors share structural but not functional homology with FGFs. J. Biol. Chem., 2003, vol. 278, no. 36, pp. 34226-34236. DOI: 10.1074/jbc. M303183200

22. Itoh N., Ornitz D.M. Evolution of the Fgf and Fgfr gene families. Trends Genet., 2004, vol. 20, no. 11, pp. 563-569. DOI: 10.1016/j.tig.2004.08.007

23. Ferrara N., Gerber H.P., LeCouter J. The biology of VEGF and its receptors. Nat. Med., 2003, vol. 9, no. 6, pp. 669-676. DOI: 10.1038/nm0603-669

24. Monk B.J., Willmott L.J., Sumner D.A. Anti-angiogenesis agents in metastatic or recurrent cervical cancer. Gynecol. Oncol., 2010, vol. 116, no. 2, pp. 181-186. DOI: 10.1016/j.ygyno.2009.09.033

25. Rotar I.C., Dumitras D.E., Popp R.A., Petrisor F.M., Cotutiu P., Stamatian F., Muresan D. VEGF +936 C/T Genetic Polymorphism in Patients with Cervical Dysplasia. Anal. Cell. Pathol. (Amst), 2016, vol. 2016, pp. 6074275. DOI: 10.1155/2016/6074275 
26. Zhao X.M., Wang E.B., Li J.J., Zhou C.F., Zhao Q., Zhang L.J. [Developmental changes of acetabular cartilage complex: an experimental study of a straight-leg swaddle model of newborn rats]. Zhongguo Dang Dai Er Ke Za Zhi, 2009, vol. 11, no. 10, pp. 836-840. (in Chinese)

27. Alekseeva L.I., Zaitseva E.M. Klinicheskie podkhody k lecheniiu osteoartroza [Clinical approaches to osteoarthrosis treatment]. Russkii Meditsinskii Zhurnal, 2006, vol. 14, no. 6, pp. 450-453. (in Russian)

28. Badokin V.V. Puti optimizatsii terapii osteoartroza [Ways of osteoarthrosis optimization]. Russkii Meditsinskii Zhurnal, 2006, vol. 14, no. 25, pp. 1824-1828. (in Russian)

Received: 12.03 .2020

\section{Information about the authors:}

1. Irina V. Musikhina, M.D., Ph.D.,

Privolzhsky Federal Medical Research Centre, Nizhny Novgorod, Russian Federation, Email: i_musihina@mail.ru

2. Anna B. Yazykova, M.D., Ph.D.,

Privolzhsky Federal Medical Research Centre, Nizhny Novgorod, Russian Federation

3. Maksim V. Vlasov, M.D., Ph.D.,

Privolzhsky Federal Medical Research Centre, Nizhny Novgorod, Russian Federation

4. Natalia A. Gordinskaia, M.D., Ph.D.,

Privolzhsky Federal Medical Research Centre, Nizhny Novgorod, Russian Federation

5. Mikhail Yu. Lebedev, M.D., Ph.D.,

Privolzhsky Federal Medical Research Centre, Nizhny Novgorod, Russian Federation

6. Dina Ya. Aleinik, M.D., Ph.D.,

Privolzhsky Federal Medical Research Centre, Nizhny Novgorod, Russian Federation

7. Nikolai A. Tenilin, M.D., Ph.D.,

Privolzhsky Federal Medical Research Centre, Nizhny Novgorod, Russian Federation 